\title{
AVOIDING SEXIST PRONOUNS
}

Michael P. Jordan

Jennifer J. Connor

\section{Background}

During a recent tour a gracious host proudly pointed out to his female guest one of his city's many liftbridges, noting that it was designed by a woman engineer and worked very well. After a pause he quickly added, "of course, they all work well." Evidently he realized that in his enthusiasm he had inadvertently uttered a patronizing sexist statement.

This kind of subconscious sexism--a "gee whiz" attitude to a woman's professional ability--is still legion; nevertheless, as this anecdote also shows, there is an increased awareness of the problem. Awareness of sexism--especially in language--has grown out of the discussions and publications of the last two decades. In this paper we will briefly review some of the major themes in the literature, referring to Canadian works whenever possible, and offer practical ways to overcome one of the most common problems of sexism in writing: the inappropriate use of gender-specific pronouns.

Although inappropriate sexist language is that which discriminates against either sex, historically it tends to exclude (or to imply exclusion of) women, or to stereotype women in certain roles. A wealth of material has been published on sexist language, ranging from early anecdotal or impressionistic works to more recent research studies. While the following overview is not by any means exhaustive, it refers to works which are representative of the types avallable. Publications on sexist language in general include linguistic, communication and philosophical studies [1-11], practical "how-to" works for professionals $[12-16]$, publishers' recommendations $[17-20]$, and the recommendations of special interest groups and federal government departments, particularly in Canada [21-30]. Increasingly writers ' manuals are devoting brief sections to sexist language [31-34], and whole manuals on the art of nonsexist and other nondiscriminatory language have appeared [35-37]. One study suggests that editors of company newsletters, at least, may have heeded the advice provided in such works [38]. American business and technical communication literature, including textbooks, also demonstrates the concern for nonsexist language (although much of 
the discussion in this field is still derivative and prescriptive) [39-45]. Unfortunately, more needs to be done in Canada. 1

\section{Four Areas of Sexism}

Generally speaking, the focus in all these publications has been on four main areas of sexism in English: different courtesy titles for men and women; separate occupational titles for men and women performing the same job; the use of "man" to refer to people in general; and the use of "he," "his," and "himself" to include women. Handling the first three problems has been relatively straight forward.

First, many women adopted the courtesy title "Ms" to denote a status equivalent to men ("Mr."); by removing the indication of marital status of the traditional titles "Mrs." and "Miss," use of this neutral title sought to change a perception that an indication of women's marital status somehow subordinated women to men. (This trend is reversing: many women now do not use "Ms" [41, p.25; 11, p.164], probably because of its association with early strident feminism or because they choose to indicate marital status.) Perhaps another approach is to change men's courtesy titles using the rather archaic "Master" as well as "Mister." In business correspondence, however, it is becoming customary to eschew courtesy titles altogether: both women and men use full names in the signature line and sometimes in the salutation (as in "Dear John Smith").

Second, organizations have changed position titles so that they are no longer gender-specific; and in some countries, including Canada, governments have published dictionaries of new occupational titles [47]. Noticeable changes in Canada, for example, include "flight attendant" in place of the former "steward/stewardess"; "police officer" for "policeman/policewoman"; "letter carrier" for "mailman" and "server" for "waiter/ waitress." Most of these titles happily avoid the clumsiness of changing the "man" suffix to "person." Whole government agencies and other organizations have also changed their names to reflect their actual constituency: Canada Manpower has become Canada Employment Centre; the Workmen's Compensation Board has become the Workers' Compensation Board; and the National Museum of Man has become the Canadian Museum of Civilization.

lFew Canadian works on business and technical communication exist, and those that are available do not include discussions of sexist or nonsexist language. One notable change has occurred, however: Ron Blicq's popular Technically-Writel reflects nonsexist usage in its subtitle. Originally published as "Communication for the Technical Man" in 1972, it became "Communicating in a Technological Era" in its second edition in 1983 [46]. 
Third, writers have consciously avoided using "man" to refer to everyone. A notable, and now classic example, is anthropologist Peter Farb's 1978 work Humankind, in which he explained his deliberate choice of the nonsextst noun in his title [48]; only ten years earlier Farb had used the conventional generic noun in his Man's Rise to Civilization as Shown by the Indians of North America. In addition to "humankind, "other collective nouns avoid the implication that women are excluded: people, society, human race, humanity, etc. However, we still need to resolve such problems as manhole, man overboard, one-upmanship, horsemanship, manslaughter, man-eater, man-hunt; the "man-girl" inequality as in man Friday/girl Friday; and the unnecessary qualifier in "woman engineer," "woman lawyer," etc.

Other problems with sexism have been identified in the literature, including the demeaning reference to women according to their physical attributes (e.g., "the blonde"), their lower occupational status (e.g., "the giris in the office"), and their implied possessive relationship to men as in "man and (his) wife". These problematic descriptions are harder to correct, except the last one, which we now accept as "husband and wife." More subtle problems sometimes occur: a recent example in an. Ontario university newsletter informed readers that at the Learned Societies Conference "the expected attendance of the Royal Society of Canada is 350 people, including wives and children." In a letter to the editor, a scientist expressed her dismay at the implication that either there were no female fellows of the Royal Society or husbands do not attend conferences.

\section{The Pronoun Problem--Comion Solutions}

Despite such occasional slips, the above solutions for courtesy and occupational titles and the generic use of "man" clearly show that much has been achieved toward the goal of nonsexist language, particularly in the workplace. A continuing concern which has no easy solution, however, is the use of the generic pronoun "he" and its variants to refer to a collective noun or to one which is not gender-specific. For example, in the sentence "The applicant must bring his resume" the pronoun "his" is grammatically correct but tends to imply that women are not included in the statement. Attempts to overcome this problem can sometimes lead inadvertently to stereotyping; for example, the use of the fenale pronoun in an advertisement for a community nurse-"The successful applicant must have her own car"--can leave the erroneous impression that only a woman can fill the position. Unfortunately, the use of "he" consistently with an explanatory note indicating that the pronoun refers to both sexes, though common in legal documents, shows a lack of concern for the reader; moreover, this attempted solution does not remove the perceived inequity in the language. Studies have indicated, in fact, that 
the word "he" does not conjure up images of both sexes in the minds of readers, but only the single image of "male" $[9, p p .73-$ $74 ; 35, p p .35-38 ; 43, p .87]$. To avoid these potential pitfalls, writers have advanced a variety of solutions. The most common suggestions, perhaps, are the following:

1. invent a new pronoun;

2. alternate male and female pronouns;

3. use "he or she";

4. use "they" as a singular pronoun;

5. pluralize the noun;

6. use the second-person pronoun or the neutral "one";

7. eliminate the pronoun reference.

While these suggestions can be useful, they can also be problematic, especially for use in functional communications.

1. Since the eighteenth century writers have proposed upwards of eighty new English pronouns to convey the meaning of both sexes in the same singular word $[10$, p.190]. Here are just a few of the suggestions $[4$, p.131; 10, pp.205-209; $11 ; 35$, p.47; 49]:

thon/thons
co/cos/coself
E/E's/Em
na/nan/naself
e/es/em
she/heris/herim
she/shis/shim
re/vis/ver

\author{
tey/tem/ter(s) \\ hesh/hizzer/himer \\ hir \\ heshe/himer/hiser \\ on \\ s/he \\ ho/hom/hos/homself \\ hue/hues/hume
}

While the intent behind their invention is laudable, these neologisms have failed to gain support or interest, have been treated with contempt or derision, and have been used only rarely, if at all. Without general acceptance they become barriers to communication themselves and so are not suitable solutions for any genre of writing.

2. Some writers have alternated pronoun gender from sentence to sentence or within larger units (paragraph to paragraph or chapter to chapter) to refer to both sexes equally. However, this technique can lead to confusion and tedium for the reader, and so is not recommended for functional communications.

3. Using "he or she" and similar expressions can also give equal attention to both sexes, but can clutter up writing and generally is clumsy. Too many can mar any communication, and so "he or she" (or "s/he") must be used sparingly.

4. "They" and "their" are used frequently as singular pronouns in everyday speech--it is simpler and more natural to say "Everyone must bring their own beer" than to use "Everyone must bring 
his own beer." Although the use of the plural pronoun has been sanctioned by well-known writers for centuries, and has been proscribed by grammarians only in the last two hundred years [2], it is still often censured for formal writing. Therefore, using the plural form is not recommended in formal technical or business communications.

5. A more efficient and less clumsy method is to pluralize both the noun and the possessive pronoun. Thus "Everyone must bring his own beer" becomes "Partygoers must bring their own beer." Yet this approach may not always be ideal--especially if you want to personalize the communication.

6. To personalize, the second-person pronoun can be used. Thus "Everyone must bring his own beer" becomes "You must bring your own beer," which is suitable for singular or plural you.

7. Often writers eliminate the pronoun altogether. Thus "Everyone must bring his own beer" becomes "Everyone must bring beer." However, the sense may change in the process. For example, if this revision does not convey exactly the same message (since it is conceivable that someone does not drink beer, why bring (t?), then minor changes are required to improve the sentence, depending on the context: "Anyone who wants to drink beer at the party must bring it."

These suggestions applied singly do not always achieve the goal of nonsexist communication. Nevertheless, conscious attempts to combine them and other approaches will increase the nonsexist tone throughout a piece of writing. The aim should be to minimize sexist expressions in an efficlent, invisible way, to write in as neutral a manner as possible. The reader should neither be conscious of awkward attempts at unblased writing nor feel the attempts overpower the message through overuse [38].

\section{The Pronoun Probles--0ther Solutions}

In addition to these seven commonly identified ways of reducing the number of sexist pronouns, writers often of fer examples of "writing around the problem" or "recasting" the sentence. In general, however, they do not identify the specific grammatical techniques used; moreover, seldom do they of fer more than one or two examples of "recasting." Perhaps the most detailed exception so far is that of Christian [43], who shows eight ways to substitute other pronouns and four ways to eliminate troublesome pronouns.

The following list represents an attempt to identify more fully the specific ways to avoid the use of generic pronouns. The list offers a preliminary classification of techniques with 
examples. In each pair of examples, the first phrase uses a male pronoun and the second gives an alternative which avoids it. The main goal of the list is to outline specific methods for writers and teachers of writing to achieve nonsexist communication. Perhaps it might also form a basis for detafled research into gender-specific pronouns, their use and their effects on tone, style and propriety in technical and business writing. Finally, teachers may find that an in-class analysis of the large variety of methods used to avoid sexist pronouns can form an interesting and informative introduction to sentence and clause structures in expository prose. To encourage teachers to try these analyses, a brief exercise with suggested answers follows the list of solutions.

\section{THE PROMOUN PROBLEN - OTHER SOLUTIONS}

\section{DEFINITENESS AND PLURALITY}

\section{Definite Article}

If the teacher is aware that his lesson will be assessed...

If the teacher is aware that the lesson will be assessed...

2. Indefiniteness

... for the teacher to walk into his class...

...for the teacher to walk into _class...

\section{Indef inite Article}

Perhaps the student's problem is more basic still: his inability to...

Perhaps the student's problem is more basic still: an inability to...

\section{Unarticled Plural}

The teacher should use visual aids in presenting his lessons.

The teacher should use visual aids in presenting lessons. 
5. Unarticled Singular

The successful applicant must send his acceptance within a month.

The successful applicant must send acceptance within a month.

\section{Consistent Plural}

The successful language student can be encouraged to explain how he has analyzed his exercise.

Successful language students can be encouraged to explain how they have analyzed their exercises.

\section{Inconsistent Plural}

No one failing this course can complete his program.

No one failing this course can complete their programs.

\section{CONTINUITY}

\section{Full Repetition}

How can the teacher help language learners? He can...

How can the teacher help language learners? The teacher can...

\section{Partial Repetition}

The child who has been well nurtured becomes a well-balanced adult. He is better able to...

The child who has been well nurtured becomes a well-balanced adult. The well-nurtured child is better able to...

\section{Generic Moun}

When a student makes an utterance that needs expansion or rephrasing, he can be encouraged to do this.

When a student makes an utterance that needs expansion or rephrasing, the speaker can be encouraged to do this. 


\section{Synonym}

The student needs to acquire the ability to infer meanings in words. He must al so discover...

The student needs to acquire the ability to infer meanings in words. The pupil must also discover...

\section{Acronve}

The psychologically deprived child can become a serious problem in society. He often Tater resorts to violent and criminal acts.

The psychologically deprived child can become a serious problem in society. The PDC often later resorts to violent and criminal acts.

\section{Untriggered Associate/Perspective}

The diligent student can expect to receive good grades for his work.

The diligent student can expect to receive good grades.

\section{DESCRIPTIVE CLAUSES}

NOTE: The following examples of descriptive clauses are all non-defining; however, it is probably possible to use defining clauses for these categories to avoid sexist pronouns. e.g. "Teachers who always consider the use of visual aids may nevertheless find them unsuitable for some purposes."

\section{Relative Clause}

The teacher should always consider the use of visual aids. He may find them unsuitable for some purposes, however.

The teacher, who should always consider the use of visual aids, may find them unsuitable for some purposes.

\section{5. -ed Clause}

The language learner may be faced with living in the target country. He will then undergo "culture shock." 
The language learner, when faced with living in the target country, will undergo "culture shock."

NOTES: 1. -ed clauses can of ten be reduced to a single adjective (e.g., "questions which he has attempted" becomes "questions attempted" or "attempted questions").

2. -ed clauses are, of course, agentless passives.

16. -ing Clause

The teacher writes the vocabulary on the board. He then separates the different parts of speech.

The teacher writes the vocabulary on the board, separating the different parts of speech.

\section{Verbless Clause}

The student is usually eager to learn real-life language. But he may be less keen to learn grammar.

The student, usually eager to learn real-life language, may be less keen to learn grammar.

\section{8. to-Infinitive Clause (Passive)}

The winner will be announced next class. He will be presented with the award on Founders' Day.

The winner, to be announced next class, will be presented with the award on Founders 'Day.

\section{9. to-Infinitive Clause (Active)}

The writer's aim is to create a plausible sales message. He can only achieve this by providing convincing information.

The writer's aim, to create a plausible sales message, can only be achieved by providing convincing information.

\section{Apposition}

The whale is the largest mammal on earth. He constantly migrates along continental shorelines. 
The whale, the largest mammal on earth, constantly migrates along continental shorelines.

\section{Wth}

We were dealing with the highly motivated student. He generally had a broad linguistic background.

We were dealing with the highly motivated student, generally with a broad Iinguistic background.

\section{ELLIPSIS}

22. Subject Ellipsis (Active)

The teacher can collect sentences of various structures and he can group them...

The teacher can collect sentences of various structures and can group them...

\section{Subject Ellipsis (Active - Passive)}

The student pays fees to the Home University; he is classed as a "visiting graduate student" at the Host University where no fees are paid.

The student pays fees to the Home University and is classed as a "visiting graduate student" at the Host University where no fees are paid.

24. Subject-Modal Ellipsis

The student must attend regularly and he must submit all assignments on time.

The student must attend regularly and submit all assignments on time.

\section{Subject-Yerb Ellipsis}

The student may feel that certain things are inadequately expressed in English. He may also feel that some things are not adequately expressed in Clluba. 
The student may feel that certain things are inadequately expressed in English and that some things are not adequately expressed in Ciluba.

\section{Adjunct Replacement}

The teacher can help students use actives and passives together by analyzing formal description. He can also help them do this by having them write such texts.

The teacher can help students use actives and passives together by analyzing formal description and by having them write such texts.

\section{List}

The teacher can bring humour into the classroom. He can change the pace. He can make learning a joy...

The teacher can bring humour into the classroom, can change the pace, and can make learning a joy...

INFORMAL USES

28. You/Your

The student's assignment is to learn a new tense. He is given a list of regular verbs to select from.

Your assignment is to learn a new tense. You are given a list of regular verbs to select from.

\section{We/Our}

The teacher seldom gets ready-to-use directions from grammarians. He can, however, produce his own.

We seldom get ready-to-use directions from grammarians. We $\overline{c a n}$, however, make our own.

30. I

If the teacher had to express the same ideas, could he use the same structures and words?

If I had to express the same ideas, could $I$ use the same structures and words? 


\section{Inperative}

The student should answer the easy questions first. He should then re-read and answer the rest.

Answer the easy questions first. Then re-read and answer the rest.

FORHUL USES

32. One/One's

The student should always re-read his examination responses.

One should always re-read one's examination responses.

NOTE: The UK system one....one, though frequently considered rather pompous, must now be preferred over the US one....he.

\section{Agentless Passive}

The teacher asks a question, and throws a ball to a student, who answers and returns the ball. He can vary this procedure in a number of ways.

The teacher asks a question and throws a ball to a student who answers and returns the ball. This procedure can be varied in a number of ways.

(Also see -ed clauses earlier.)

\section{Agentive Passive}

The student sometimes submits essays written by others. To receive credit, all work he submits must be his own.

The student sometimes submits essays written by others. To receive credit, all work submitted by a student must be written by that student.

NOTE: The agent in an agentive passive can be any form of continuity except, of course, a personal pronoun (e.g., by him); here repetition is used. 


\section{SUBSTITUTE CL.AUSES}

\section{Inverted}

The writer may wish to delay stating the agent as long as possible. He can do this by using a by-phrase at the end of the sentence.

The writer may wish to delay stating the agent as long as possible. A by-phrase at the end of the sentence can serve this purpose.

\section{Combined}

The teacher can guide learners into habits of intelligent guessing froin context. He does this by a kind of catechism of leading questions.

The teacher can guide learners into habits of intelligent guessing from context, by a kind of catechism of leading questions.

(Also see Adjunct Replacement earlier.)

\section{IPPLICIT CONNECTION}

\section{Indirect Object}

It is easier for a student to remember the correct use of expressions if they are presented to $\mathrm{him}$ in meaningful sentences.

It is easier for a student to remember the correct use of expressions if they are presented ___ in meaningful sentences.

\section{Object}

If the student is asked for the passive counterpart, it does not help him much to know the transformational "rules."

If the student is asked for the passive counterpart, it does not help _ much to know the transformational "rules." 


\section{Reflexive}

If a student misbehaves himself on the trip, appropriate act on wil be taken.

If a student mi sbehaves wil be taken. on the trip, appropriate action

40. Subject with Anticlpatory "It"

At some time the teacher can simply state that something is wrong. At other times it may be worthwhile for him to ask the student to explain the answer.

At some time the teacher can simply state that something is wrong. At other times it may be worthwhile to ask the student to explain the answer.

\section{Temporal -ing Clause}

It is inadvisable for a trainee to use a new aid if he is giving a practical test.

It is inadvisable for a trainee to use a new aid while giving a practical test.

42. Ifwe Adjunct

The gifted student may lose interest in academic work in his youth.

The gifted student may lose interest in academic work during youth.

\section{OTHER}

\section{Modal Infinitive}

The student needs to be seated so he can see all information presented. (or "to enable him to see")

The student needs to be seated so as to be able to see all information presented. 
44. Existential "There"

The teacher often has difficulty teaching articles and prepositions to ESL students from China. He can, however, simplify the task.

The teacher often has difficulty teaching articles and prepositions to ESL students from China. There are ways, however, of simplifying the task.

\section{Noun Complenentation}

The student may, within two days, rewrite the essay rejected by the teacher and require him to accept it.

The student may, within two days, rewrite the essay rejected by the teacher, and require its acceptance.

46. Defining Coaplex Subject

If a student is aware of damage being done in residences, he has a duty to report it.

Any student aware of damage being done in residences has a duty to report it.

NOTES: 1. Relative, -ed, -ing, and verbless clauses can form part of the complex defining subject; a verbless clause is used here.

2. Triggered reflexive associates ("a student whose grade is...") are al so used.

\section{Nominative Noun}

Should a student prove disruptive during a practice session, he will be required to withdraw from the program.

Should a student prove disruptive during a practice session, withdrawal will be required.

48. Purpose Clause

The local successful applicant will be sent an application form and he will be asked to complete and return it for the regional competition. 
The local successful applicant will be sent an application form to complete and return for the regional competition.

\section{Direct Verb}

The student may make his selection of electives from those Tisted for the department.

The student may select electives from those listed for the department.

\section{Intransitive Yerb}

The graduate student needs a supervisor who can assist and stimulate him effectively throughout the program.

The graduate student needs a supervisor who can function effectively throughout the program. 


\section{EXERCISE IN AYOIOING SEXIST PROMOUNS}

Use various methods of avoiding the sexist pronouns in the following.

1. By frequently and quickly responding to journals, the instructor can avoid long weekends of journal reading, and she can monitor the progress of each student.

2. If the purpose of the journal is to prepare for class, the instructor might explain that she will call on the student to read from his journal.

3. When an instructor explains the weight of the journal, she can also explain how she will grade the entries.

4. If the instructor wants the student to react to class lectures and respond to readings, she could give him a model entry for his journal.

5. If a student wants to study at another approved university outside Ontario:

(a) he must register as a full-time resident and he must pay his fees at the other university. During his period away from this university, he must maintain his registration here; however, he will be exempted from paying his tuition fees for that period. For the period to be counted towards his residence, the work he performs must be equivalent to that which he would have accomplished over a similar period at this university.

6. Each town reeve applicant must list two persons whom she has asked to submit confidential letters about her ability.

7. A candidate for this award must be a citizen of Canada, or he must have held landed imnigrant status for one year prior to his submitting the application.

8. Unsatisfactory performance by the student may cause proceedings to be instituted requiring him to withdraw from his programme.

9. If a student can demonstrate that his transcript is in some way misleading, he may appeal to the Board of Studies to have the error corrected.

10. Assuming a student attempts four or more courses during the year, and his average performance in the courses which he has passed is less than 60 per cent, he will be placed on probation. By the end of his probationary period he must 
have raised his overall average on all courses which he has passed to at least 60 per cent, or he will be required to withdraw.

11. The customer makes her selection from about 2,500 items displayed behind transparent panels so that she can see the products but she cannot remove them. She inserts a small plastic card in a slot and she presses a button to select her item. She then receives the item she has selected, and she puts it in her cart.

12. Having assessed the manner in which his particular industry Is likely to expand over the future years, the plant manager or engineer may not experience too much trouble in roughly estimating an optimum layout for the plant which could serve him efficiently for at least ten years into the future. He will then find, however, that there is no way in which the existing production volume of the plant can support the immediate construction cost of his complete new facility. This is because he must obviously initiate the construction process on his current operational budget, while the reason he needs the new facilfties is because his operational budget is too low.

\section{ANSUERS}

1. and can monitor (subject ellipsis)

2. that students will be asked to read from their journals (agentless passive, plural)

3. When explaining...the instructor can also explain how the entries wII be graded. (temporal -ing preceding main clause, passive)

4. students... readings, it might be a good idea to give them a model entry. (plurai, anticipatory it, plural, untriggered associate)

5. (a) the student must register as a full-time resident and pay fees at the other university. During the period away from this university, the student must maintain registration here, but will be exempted from paying tuition fees for that period. For the period to be counted towards residence, the work performed by the student must be equivalent to that which would have been accomplished over a similar period at this university. (full repetition, ellipsis, unarticled plural, definite article, full repetition, unarticled singular, subject ellipsis-passive, unarticled singular, agentive passive with full repetition, agentless passive) 
6. who has been asked... about the applicant's ability. (agentTess passive, partial repetition)

7. or have held...prior to submitting the application (subject-modal ellipsis, temporal-ing)

8. requiring withdrawal. (noun complementation, untriggered associate)

9. Any student who can demonstrate that the transcript...may appeal (defining relative clause, definite article)

10. A student who has attempted four or more courses during the year and whose average performance in courses passed is less than 60 per cent will be placed on probation. By the end of the probationary period the student's overall average on all courses passed must have been ralsed to at least 60 per cent, or withdrawai will be required. (defining complex subject with defining relative and triggered associate clauses, defining -ed clause as predicative adjective, definite article, full repetition, defining -ed clause as predicative adjective, agentless passive, nominative noun)

11. makes selections (or selects)...so that they can be seen but not removed. After inserting a small plastic card in a slot and pressing a button, the customer receives an item to put in the cart (unarticled plural (or direct verb), agentless passive, agentless passive, temporal -ings, full repetition, indefinite article, purpose clause, definite article)

12. ...the particular industry... The entrepreneur will then find...could operate efficiently...cost of the complete new facility. This is because the construction process must obviously be initiated on the current operational budget, while the reason the new facilities are needed is because the operational budget is too low. (definite article, intransitive verb, generic noun, definite article, agentless passive, agentless passive, definite article)

\section{REFERENCES}

We would like to thank reviewers of this journal and our students for helpful suggestions.

1. Lakoff, Robin. 1973. Language and Woman's Place. Language in Society $2: 45-50$.

2. Bodine, Anne. 1975. Androcentrism in Prescriptive Grammar: Singular "They," Sex-Indefinite "He," and "He or She." Language in Society $4: 129-46$. 
3. Stanley, Julia P. 1977. Gender-Marking in American English: Usage and Reference. In Sexism and Language. Alleen Pace Nilsen, et al., eds., pp. 43-74. Urbana, IL: National Councli of Teachers of English.

4. Martyna, Wendy. 1978. What Does "He" Mean? Use of the Generic Masculine. Journal of Communication 28:131-38.

5. Bate, Barbara. 1978. Nonsexist Language Use in Transition. Journal of Communication 28:139-49.

6. Purnell, Sandra E. 1978. Politically Speaking, Do Women Exist? Journal of Communication 28:150-55.

7. Orasanu, Judith, Mariam K. Slater, and Leonore Loeb Adler. 1979. Language, Sex and Gender: Does "La Difference" Make a Difference? New York: New York Academy of Sciences, Vol. 32.

8. Vetterling-Braggin, Mary, ed, 1981. Sexist Language: A Modern Philosophical Analysis. Littlefield: Adams.

9. Frank, Francine, and Frank Anshen. 1983. Language and the Sexes. Albany: State University of New York Press.

10. Baron, Dennis. 1986. Grammar and Gender. New Haven: Yale University Press.

11. Bolinger, Dwight. 1987. Blas in Language: The Case of Sexism. In Language, Communication and Education. Barbara M. Mayor and A.K. Pugh, eds., Pp. 153-66. London: Croom Helm.

12. Wendlinger, Robert M., and Lucille Matthews. 1973. How to Eliminate Sexist Language from Your Organization's Writing: Some Guidelines for the Manager and Supervisor. In Affirmative Action for Women: A Practical Guide. Dorothy Jongeward and oru Scott, eds. pp. 309-30. Reading, MA: Addison-Wesley.

13. Stiegler, Christine B. 1980. The Art of Nonsexist Communication. How to Personalize Your Communication Techniques. Management World 9(June) $: 13-15 ; 36$.

14. Colwill, Nina. 1983. Sexist Language: Sex Role Liberation's Pettiest Issue? Business Uuarterly 48(July):6;20.

15. Pickens, Judy E. 1984. Language for All: How to Write and Speak Without Bias. Management Horld 13(November):34-35. 
16. Newsom, Douglas Ann. 1986. Desplte Progress, Sexism in Language Persists. Public Relations Journal 42(August):5.

17. APA Task force on Issues of Sexual Bias in Graduate Education. 1975. Guidelines for Nonsexist Use of Language. American Psychologist 30:682-84.

18. Guidelines for Nonsexist Use of Language in NCTE Publications. 1977. In Sexism and Language. Alleen Pace Nilsen, et al., eds., pp. 181-91. Urbana, IL: National Council of Teachers of English.

19. McGraw-Hill Book Company. [1980s]. Guidellnes for Bias-Free Publishing. Hightstown, NJ: McGraw Hill Book Company.

20. Prentice-Hall College Division Guidelines on Sexism. 1983. In Communication Systems and Procedures for the Modern Office. Nathan Krevolin, pp. 439-46. Englewood Cliffs: Prentice-Hall.

21. Graham, Alma. [1980s]. Words that Make Women Disappear. Toronto: Ontario Status of Women Council.

22. Treasury Board of Canada. 1982. Elimination of Sexual Stereotyping. Administrative Policy Manual. Ch. 484. Ottawa.

23. Conseil du Trésor. 1983. Lignes directrices relatives à la suppression des stëréotypes sexuels. Manuel de la politique administrative. Ch. 484. Ottawa.

24. Employment and Immigration Canada/Emploi et Immigration Canada. 1983. Eliminating Sex-role Stereotyping: Editorial Guidelines for Employment and Immigration Canada Communications 1983/ETimination des stereotypes sexuels. Ottawa: Supply and Services Canada/Approvisionnements et Services Canada.

25. Santé et Bien-Être Social Canada. 1982. Lignes directrices visant à éliminer les stéréotypes sexuels de la langue et du matériel visuel. 0ttawa: Santé et Bien-Etre Social Canada.

26. Health and Welfare Canada. 1983. Guidelines for the Elimination of Sexual Stereotyping in Language and Visual Material. 0ttawa: Health and Welfare Canada.

27. Sah, Manju, and Catherine Rancy. 1984. Guidelines for Non-sexist Writing/Vers un langage non sexiste. [0ttawa]: Canadian Advisory Councll on the Status of Homen/Conseil consultatif canadien de la situation de la femme. 
28. Efchler, Margrit, and Jeanne Lapointe. 1985. On the Treatment of the Sexes in Research/Le traitement objectif des sexes dans la recherche. Jeanne Lapointe et Margrit Eichler. 0ttawa: Social Sciences and Humanities Research Council of Canada/Conseil de recherches en sciences humaines du Canada.

29. Correctional Service Canada/Service correctionnel Canada. 1985. On Equal Terms: How To Eliminate Sexism in Communications/D'Egal à égale: quelques moyens d'eliminer les elements sexistes des communications. ottawa: Minister of Supply and Services Canada/Ministre des Approvisionnements et Services.

30. Veterans Affairs Canada/Anciens Combattants. 1986. Beyond Stereotypes: Communicating Without Bias/L'Ëcueil des steréotypes: Comment T'eviter. Ottawa: Veterans Affairs/Anciens Combattants.

31. Secretariat d'État du Canada. 1983. Guide du rēdacteur de l'administration fëdērale. Ottawa: Approvisionnements et Services Canada.

32. Department of the Secretary of State of Canada. 1985. The Canadian Style. A Guide to Writing and Editing. Toronto: Minister of Supply and Services Canada.

33. Messenger, William E., and Jan de Bruyn. 1986. The Canadian Writer's Handbook. 2nd ed. Scarborough: Prentice-Hall Canada.

34. Sabin, William A., and Sheila A. O'Neill. 1986. The Gregg Reference Manual. 3rd Canadian ed. Toronto: McGraw-Hill Ryerson.

35. Miller, Casey, and Kate Swift. 1980. The Handbook of Nonsexist Writing. New York: Barnes \& Noble.

36. International Association of Business Communicators. 1982. Without Bias: A Guidebook for Nondiscriminatory Communication. 2nd ed. New York: John Wiley \& Sons.

37. Sorrels, Bobbye D. 1983. The Nonsexist Communicator: Solving the Problems of Gender and Awkwardness in Modern English. Englewood Cliffs: Prentice-Hall.

38. Cline, Carolyn Garrett, and Lynn Masel-Walters. 1983. At Least the Editors are Irying: Women and Sexism in Corporate Publications. ABCA Bulletin 46(3):26-30. 
39. Jameson, Daphne A. 1982. Reducing Sexually Biased Language in Business Communication. In Readings in Business Communication. Robert D. Gieselman, ed., pp. 202-210. 3rd ed. Champaign, IL: Stipes.

40. The Iceperson Cometh (As He or She or They Must to Al1). 1983. ABCA Bulletin 46(3):23-24.

41. Tibbetts, Charlene. 1983. Sex and the Language. ABCA Bullet in 46(3):24-26.

42. Paxson, William C. 1985. Nondiscriminatory Writing. In Strategies for Business and Technical Writing. Kevin J. Harty, ed., pp. 109-111. 2nd ed. San Diego: Harcourt Brace Jovanovich.

43. Christian, Barbara. 1986. Doing Without the Generic He/Man in Technical Communication. Journal of Technical Writing and Communication 16:87-98.

44. Shear, Marie. 1987. Little Cat Feet: Subtle Sexism and the Writer's Craft. The Bulletin [of ABC]. 50(1):17-18.

45. Murphy, Herta A., Charles E. Peck, and Sheila A. O'Neill. 1983. Effective Business Communications. First Canadian ed. Toronto: McGraw-Hill Ryerson.

46. Blicq, Ron S. 1987. Technically-Write! Communicating in a Technological Era. Canadian 3rd ed. Scarborough: Prentice-Hall Canada.

47. Employment and Immigration Canada. 1977. CCDO Manual of Sex-Free 0ccupational Titles. Ottawa: Minister of Supply and Services Canada.

48. Farb, Peter. 1978. Humankind. London: J. Cape.

49. Stevenson, Janet H. 1979. Who's Hue? An Alternative Generic Pronoun. Journal of Communication 2:238-39.

Michael $P$. Jordan teaches technical writing and rhetoric at Queen's University, Kingston, Ontario.

Jennifer J. Connor teaches organizational communication at The University of Western Ontario, London, Ontario. 